\title{
TECHNICAL IMPLEMENTATION OF THE NATIONAL SPATIAL DATA INFRASTRUCTURE IN SERBIA
}

\author{
Ivan R. Aleksić, Miroslav Kuburić, Ljiljana Aleksić
}

Professional paper

The paper provides overview of research and studies covering implementation and development of the National Spatial Data Infrastructure (NSDI) concept in Serbia. Research had been done in $2011 \div 2013$, with the objective to determine situation in geo-sector and the INSPIRE Directive implementation. The results of these studies are the basis and inspiration for the creation of new technological development projects and the concept of NSDI in the period 2014 $\div 2020$. The institutions in charge of implementation of NSDI are making significant efforts in implementation of the INSPIRE Directive through regional or national projects. The present paper elaborates the achieved level of NSDI technical implementation, data, network services and provides recommendations for future development. Future development of the NSDI will be based on the accurate, reliable and updated spatial information collected with various modern technologies. The Global Navigation Satellite System (GNSS) technology and the NSDI concept are constitutive parts of the main development trends.

Keywords: data; implementation; infrastructure; spatial; technical

\section{Tehnička implementacija Nacionalne infrastrukture prostornih podataka u Srbiji}

U radu je dan pregled istraživanja i studija koje se odnose na implementaciju i razvoj koncepta Nacionalne infrastrukture prostornih podataka (NIPP) u Srbiji. Istraživanja su obavljana u razdoblju 2011 $\div 2013$ s ciljem utvrđivanja stanja u geosektoru i implementacije INSPIRE Directive. Rezultati ovih istraživanja su osnova i inspiracija za stvaranje novih projekata tehnološkog razvoja i koncepta NIPP u razdoblju 2014 $\div 2020$. Institucije nadležne za implementaciju NIPP čine značajne napore u provođenju INSPIRE direktive kroz regionalne ili nacionalne projekte. U ovom radu razmatra se dostignuta razina tehničke implementacije NIPP, podataka, mrežnih servisa i daju se preporuke za budući razvoj. Budući razvoj NIPP će se bazirati na točnim, pouzdanim i ažurnim prostornim informacijama prikupljenim s različitim suvremenim tehnologijama. Tehnologija globalnog navigacionog satelitskog sustava (GNSS) i koncept NIPP su konstitutivni dijelovi glavnih trendova razvoja.

Ključne riječi: implementacija; infrastruktura; podaci; prostorni; tehnički

\section{Introduction}

The first study in 2006 presents the concept of National Spatial Data Infrastructure (NSDI) developed World-wide, identifies the existing elements of NSDI at the national level and provides recommendation for future development of the NSDI, based on the examples of good practice [7]. Subsequently, in the year 2007, the new initiative for the NSDI implementation arises, based on the principles defined by the INSPIRE Directive (INfrastructure for SPatial InfoRmation in Europe).

Comprehensive research had been performed in the period $2011 \div 2013$ within the framework of INSPIRATION Project - The Spatial Data Infrastructure Solution for Western Balkans (EC 2011). The goal of the research during the project was for the beneficiaries (Albania, Bosnia and Herzegovina, Croatia, Macedonia, Montenegro, Serbia and Kosovo) to promote Spatial Data Infrastructure and coordinate its development in Southeastern Europe, with the idea to coordinate preparation of NSDI by beneficiaries with the INSPIRE Directive objectives [6].

Results of these researches in each of the beneficiaries had been presented in the individual studies - national reports, containing a detailed overview of current state of implementation and recommendations for further NSDI development [1,9], along with the INSPIRE Directive status in the Balkan countries [5].

In the region of the West Balkan, the institutions in charge of the spatial data infrastructure implementation are making significant efforts in implementation of the INSPIRE Directive. Due to certain similarities and the fact that the establishment of Spatial Data Infrastructure in the region is generally under the responsibility of the National Mapping and Cadastral Agencies (NMCA's), any problems in implementation of the Directive are intended to be solved in a common way, through the implementation of regional projects.

Inspired by the results of the first regional project, called INSPIRATION implemented during $2012 \div 2013$, the Swedish International Development Cooperation Agency (SIDA) supports NMCA's in the West Balkan region to establish the NSDI. The Swedish mapping, cadastral and land registration authority - Lantmäteriet, is the implementing partner, working in cooperation with the State Geodetic Administration of the Republic of Croatia, being the junior partner.

The project implementation activities are foreseen under the main working packages:

WP1: Project Management and Administration

WP2: Data Sharing Policy and Regulations

WP3: Data Harmonisation

WP4: Metadata and Quality Evaluation

WP5: Dissemination (geoportals and services)

WP6: Benefits (use case risk management and prevention).

Currently, the IMPULS project $(2014 \div 2018)$, supports the INSPIRE implementation in the West Balkan region by establishing the foundation for technical interoperability and dissemination of spatial data and services among public authorities, both nationally and regionally.

According to the bilateral agreement between the Republic of Serbia and the Republic of France, the Republic Geodetic Authority (RGA) implements the IGIS project "National Spatial Data Infrastructure (NSDI) and 
Remote Sensing Center for the Republic of Serbia", through cooperation with the French consortium "IGN France International" and "EADS Astrium".

The implemented technical infrastructure comprises flexible, fully scalable and interoperable components, well suited for the needs of public authorities and business in Serbia. In doing so, and by using a comprehensive multi-source of data, it enables a variety of spatial data to be produced such as: satellite and aerial imagery; orthophoto satellite mosaics for the nation-wide coverage; true-orthophoto for the two major cities and orthophoto for 90 towns; digital elevation models; high accuracy digital terrain model for the flood prone area; 3D topographic database; maps derived by application of remote sensing technologies for environmental, agricultural and risk management purposes, etc.

Urgent satellite imagery was acquired for the areas affected by the devastating flood in May 2014 for the west part of Serbia. The supplied imagery was analysed using the remote sensing methodology for obtaining the information on flooded areas, waterlogged soil and potential landslides. Ministries and other public authorities used the imagery with additional mapping data under the emergency management to assess the impact and the extent of damages caused by floods. Additionally, the Republic Geodetic Authority had cooperated with private sector to provide geoinformation acquired by unmanned aerial vehicles, for the towns most severely affected by floods and landslides.
The technical infrastructure for optimised data storage and management provides access to data and services via the web portals. In that manner, smooth data sharing is enabled among the public authorities that significantly underpins practical implementation of the INSPIRE network services.

The INSPIRE web portal was implemented in 2014, aiming to provide access to spatial data and products from the IGIS project, as well as other spatial data sets. The portal supports discovery and view services for spatial data. The portal is intended for users from the RGA and other public institutions that work together as partners in the implementation and use of data from the project. The portal is available at www.geoshare.rgz.gov.rs exclusively for governmental institutions, including the users' authentication procedure (Fig. 1).

On the other hand, the World Bank proposed a loan to the government of Serbia for Real Estate Management Project $(2015 \div 2020)$. The following components are proposed for implementation under the new World Bank project:

- Component A: Valuation, Property Taxation and Public Real Estate Land Management

- Component B: E-governance for enabling access to real estate information

- Component C: Institutional Development of the RGA

- Component D: Project Management.

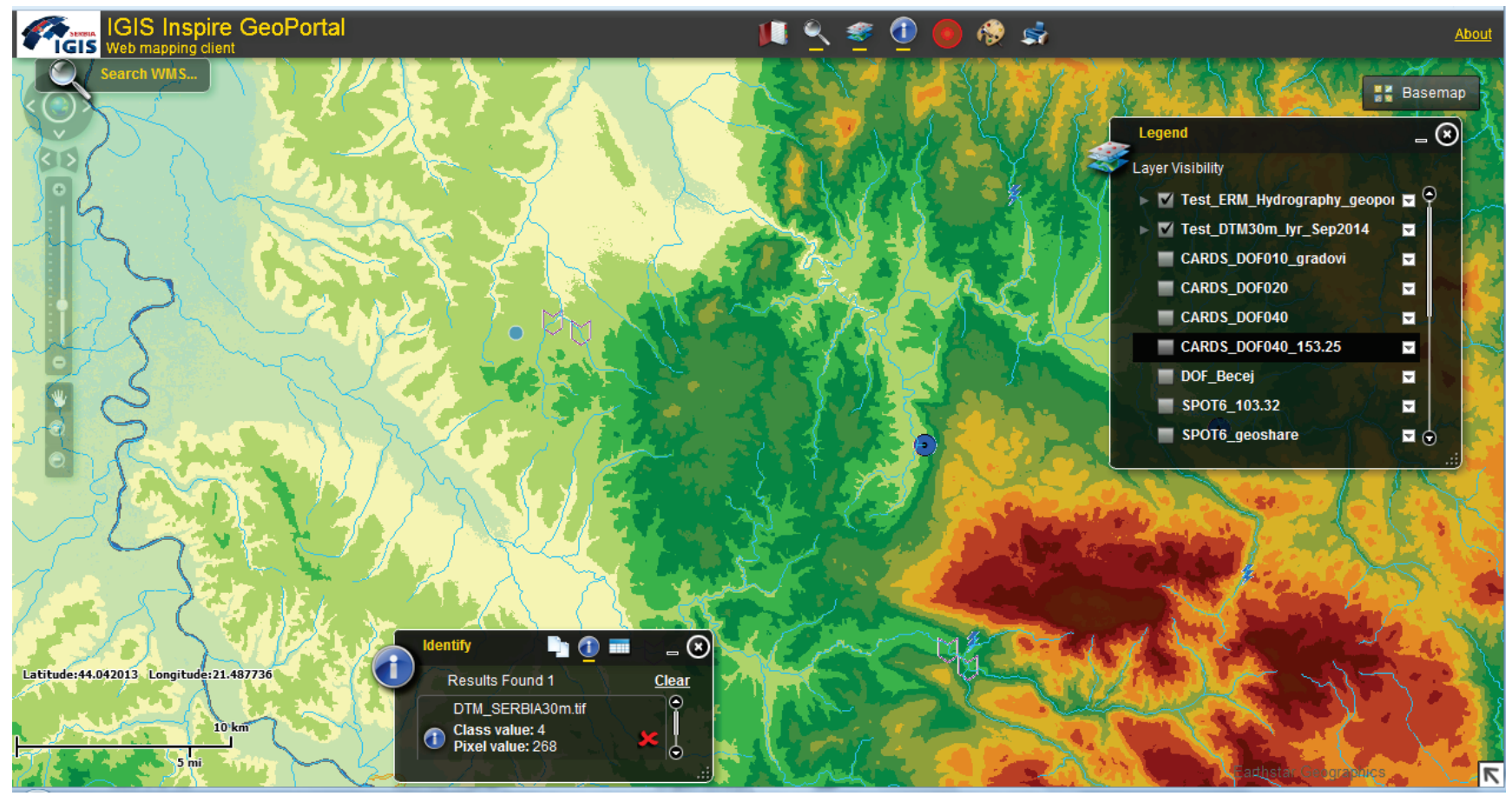

Figure 1 IGIS INSPIRE GeoPortal (www.geoshare.rgz.gov.rs)

\section{Main components of technical implementation}

Main components of the INSPIRE Directive covering technical implementation of the NSDI are: data, metadata, specification, network services, sharing data and services, monitoring and reporting .

Components of the INSPIRE Directive are defined in detail by one or more Implementing Rules (IR), with the objective to be implemented by the European Union Member States. Implementing Rules (IR) are appended by the informational INSPIRE guidelines, defining detailed technical aspects and implementation, providing for short cycles of documents updating. Data under the INSPIRE Directive are divided in 34 themes, which are grouped in 3 annexes [6]. 
Technical implementation of the NSDI requires existence of the following prerequisites:

- Components of information systems operating on different platforms;

- System consisting of various vendors' components;

- Services shall be published and available over the Internet;

- Packing the existing services, providing their exploitation as network services;

- Provision of the existing functionalities' availability for other applications on different platforms.

Application of Service Oriented Architecture (SOA) will provide for the new and the existing systems to share services, information and data, across various platforms and organizational structures. Service Oriented Architecture meets the INSPIRE requirements regarding interoperability and coordination of data and services.

\section{Data}

\subsection{Data specification}

In the NSDI technical implementation concept, standards for metadata content (for services and data) and data specification must be available. In this manner, it is possible to create a catalogue for discovery and availability of data and services using them, which further provides for data and services to be structured according to the particular requirements, being used in an interoperable manner.

Data specification is being produced in line with the INSPIRE requirements, with the objective of implementation in various NSDI's by using Generic Conceptual Model (GCM). Generic Conceptual Model provides a framework for coordinated data specification development for 34 spatial data themes defined in annexes of the INSPIRE Directive [6].

\subsection{Transformation models and formats for data exchange}

Access via the familiar Extract - Transform - Load (ETL) model provides for retrieving the existing data from database and performing transformations, in order to provide data available for services, in line with the INSPIRE requirements.

In general case, the ETL model requires tools for extraction (conversion of format) and transformation (of coordinate system and model) for the existing data, in order to adjust data to the INSPIRE requirements. It is necessary to identify data formats that can participate in this process, which may be directly exchanged between the NSDI stakeholders meanwhile.

In such a manner, data held by the NSDI stakeholders can be instantly available, and in time, through the NSDI development, coordinated with the INSPIRE Directive (using ETL model), without the need to be recreated. This provides for a more efficient approach for the NSDI development.

\subsection{Data formats}

Technical implementation of the NSDI implements the necessary, fundamental sets of formats covering the domains of: geospatial data, metadata, visualization and coordinate systems definition.

Apart from fundamental sets of formats, recommended data formats are also being used in the NSDI implementation: vector data formats, raster data formats and spatial reference system format.

\subsection{Metadata}

Creating metadata for spatial data sets and services, in line with the themes listed in the INSPIRE Directive annexes [4], along with metadata updating, holds a national importance. Metadata cover the following information:

- Coordination of spatial data sets with Implementing Rules;

- Conditions referring to access to spatial data sets and services and their use;

- Quality of spatial data sets;

- Governmental institutions in charge of production, management, maintenance and distribution of spatial data sets and services;

- Restrictions of public access and reasons for such restrictions.

Possibility of data discovery and availability is the fundamental precondition for a successful data sharing. Therefore, it is necessary for metadata describing data set or a group of data sets to be available. Metadata on services describe services available for a given data set. The basic role of metadata is to document content, structure and location of geoinformation, providing for discovery, evaluation and use.

The Republic Geodetic Authority proposed a metadata profile for spatial data sets describing: data on metadata, dataset, responsible organisation, conformity, portrayal, classification, keywords, constraints and limitations, distribution, temporal update, reference system, location and quality. The proposed metadata profile is based on:

- INSPIRE Implementation rules for metadata;

- ISO 19115 - Geographic data - Metadata;

- $\quad$ ISO 19139 - Geographic data - Metadata - XML schema.

\section{Network services}

At the national level, networks of services for spatial data sets and services for which the metadata are being formed in line with the INSPIRE Directive [6] are being established:

- Discovery services, providing for searching spatial data sets and services based on the appropriate metadata and viewing metadata contents;

- Viewing services, providing viewing, navigation, zooming, panoramic view or overlapping spatial data sets that can be viewed, and showing key data, along with any other relevant content of metadata as a minimum;

- Download services, providing for copying spatial data sets or parts thereof, including the direct access as needed; 
- Transformation services, providing for spatial data sets transformation, with the objective to achieve interoperability;

- Services providing for spatial data services use;

- Services consider regular user requirements and should be easy to use, publicly available, with the possibility of internet or any other type of telecommunication access.

It is necessary to provide for technical capacities all national-level governmental organs to link their spatial data sets and services to the network service.

\subsection{Geoportals}

Access to network services is being provided over geoportal, in line with the INSPIRE Directive [6]. Geoportal is a type of Web portal, used for discovery and access to geospatial information and accompanying services (viewing, editing, analysis, etc) over the Internet. Geoportals are important for the efficient use of Geographic Information Systems (GIS), being the key elements of the Spatial Data Infrastructure (SDI).

Geoportals are being used in practice as the platform for viewing and sharing distributed spatial data and services, contributing to the NSDI development on the territory of the Republic of Serbia, with the significance division possible to: national level, city level and local level.

\subsection{National level geoportals}

Initial geoportal GeoSerbia, as the platform for viewing and sharing distributed spatial data and services under the auspices of the NSDI, had been launched on November $27^{\text {th }}, 2009$ (Fig. 2). In that manner, public access over the Internet is available for discovery and viewing services for a limited number of metadata, spatial data sets and services under the competence of the Republic Geodetic Authority and other institutions.

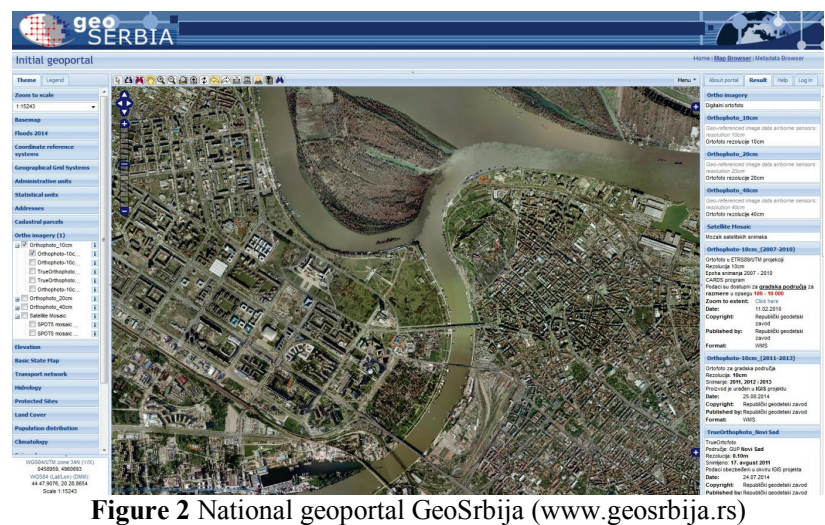

Geoportal consists of three main pages: home page, metadata browser and geodata and services browser. Home page of geoportal provides the access to the relevant information covering the NSDI establishing and development, namely:

- Documents of importance for NSDI bodies operation (legislation, strategies, rules of operation, decisions, etc);
- Documents supporting development of technical framework (standards, instructions, applications, etc); - Information and documents covering regional, European and other international activities covering SDI creation, with particular focus to the INSPIRE;

- News and presentations on the NSDI activities;

- Links to web pages of partner institutions, international projects, other geoportals, standardization organizations, etc.

Metadata browser page provides for metadata search per keywords and viewing metadata found. Metadata can cover spatial data sets available on geoportal for viewing, along with the data not published on the geoportal, yet can be described and provide more information for interested users.

Geodata and services browsing is available through map browser for available data and services, with the following fundamental functions:

- Presentation of geodata in an interoperable manner, regardless of coordinate system and projection used for storage;

- Viewing tools, providing for spatial data presentation and navigation;

- Geodata search based on the given attributes.

Initial geoportal had been developed within the framework of twinning project with the Norwegian Mapping and Cadastral Agency Statens Kartverk. Technical platform is scalable and based on Open Source software, using the tools such as UMN Mapserver, OpenLayers, PostgreSQL/PostGis and other similar solutions.

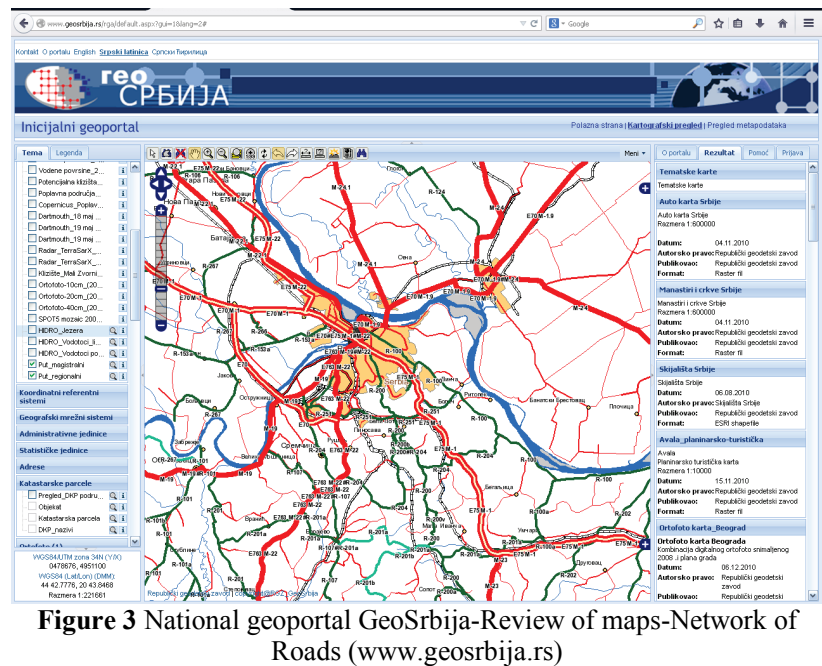

The portal currently provides data under the competence of Republic Geodetic Authority, Republic Statistics Office, Republic Seismology Authority, Republic Hydrometeorological Authority, Environment Protection Agency, Ministry of Defense - Military Geographic Institute, PE "Putevi Srbije", Institute for Environment Protection and individual local government units.

Geoportal provides access to spatial data from the official records and registries under the competence of the Republic Geodetic Authority, including coordinate 
reference system, administrative units, statistical units, addresses, cadastral parcels, orthophoto, altitudes and individual thematic maps for certain areas (Fig. 3).

Public authorities, local administration, educational and research institutions, private companies and other users use the geoportal daily for the purposes of performing regular work under their competence. Additionally, the citizens are provided with an easy access to geodata via the Internet.

Currently, the geoportal gets over user 60000 visits per month. As a result, over 8 million hits on the Map Browser are reached monthly.

\subsection{Geoportals cities}

Geoportals of Cities, contain geodata and metadata which cover areas of cities. One of the examples is geoportal of the Council of the City of Belgrade whose founder is "Directorate for Construction Land and Development of Belgrade".

Interactive map of the City of Belgrade is digital, providing for searching for addresses, buildings (education, culture, catering, etc), searching parcels per cadastral municipalities, searching through urban plans and coordinate locating option (Fig. 4).

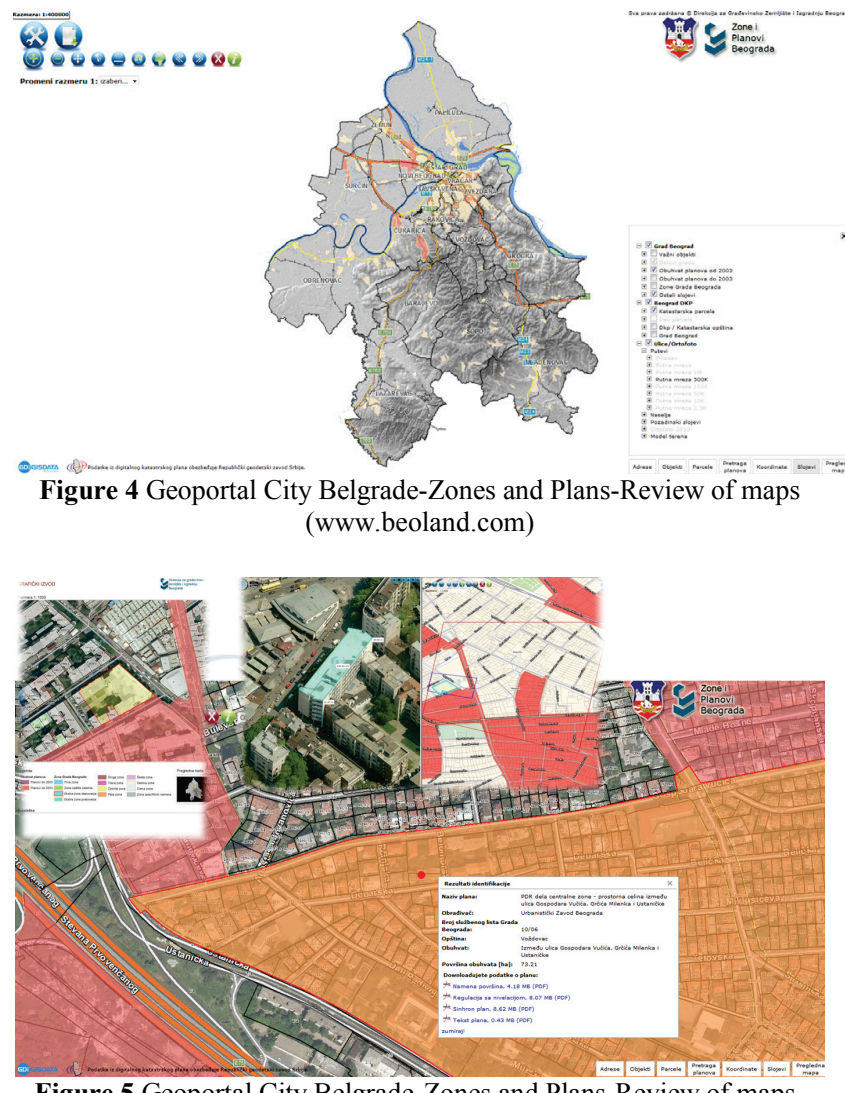

Figure 5 Geoportal City Belgrade-Zones and Plans-Review of mapsDifferent layers (www.beoland.com)

Competence of the Directorate includes managing, organizing, equipping and improving construction land and development of capital projects of importance for Belgrade. Geoportal contains diverse data sets: digital cadastral map for the territory of the City of Belgrade, digital terrain model, orthophoto, settlement view, road network, background layers (railways, islands, lakes and rivers), zones of the City of Belgrade (street names, house numbers, polygons of municipalities, areas, cemeteries, airports, fortresses, parks, stadiums and forests) and spatial plans content (Fig. 5).

\subsection{Local government geoportals}

Local government geoportals cover data related to the territories of individual municipalities on the national territory. One of the examples is geoportal of the Municipality of Subotica, with town-level Geographic Information System developed, for the purposes of development planning, managing utility and other systems, informing citizens and investors (Fig. 6).

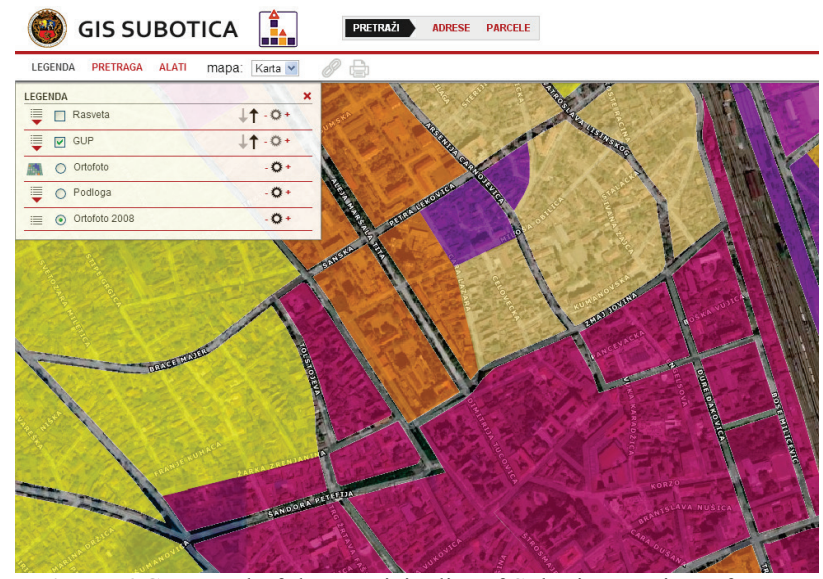

Figure 6 Geoportal of the Municipality of Subotica-Review of maps (www.subotica.rs)

Institutions participating in the GIS development are Municipality and public companies: administrative organs of the Town of Subotica, Directorate for Development of the City of Subotica, Urban Planning Authority of the City of Subotica, Water Supply and Sewage of Subotica, Sanitation and Greenery of Subotica, Heating Plant of Subotica, Suboticagas, Firefighters, Public Security, Parking service, Subotica-trans, Higher Technical School of Subotica, Chimney Sweep Subotica, Stadium, Power supply company "Elektrovojvodina", Electro distribution of Subotica, Telecommunications company "Telekom Serbija", Postal services of Serbia, Post office of Subotica, Republic Geodetic Authority unit in Subotica.

Spatial data available on the portal are: street lighting (operating and malfunctions), GUP (general urban plan), orthophoto, base maps (settlements, cadastral parcels, auxiliary buildings, main buildings, streets, railway, house numbers).

\section{Recommendations for future development}

Future development of the NSDI must be in line with the main trends in global technological and social development of the modern society, based on the accurate, reliable and updated spatial information collected using various modern technologies and procedures. The GNSS (Global Navigation Satellite System) technology and the NSDI concept are constitutive parts of the main development trends [4].

Technical implementation of the NSDI is to assist and assure added value for the community and development of information society as a whole $[2,3,8,10]$. It is 
necessary to implement standards in the NSDI framework as soon as possible and provide for further development of national geoportal, with the NSDI network services.

It is necessary to provide monitoring for NSDI technical implementation and compare data models at national geoportal and data sets of stakeholders with the INSPIRE data specification for chosen themes [6]. In the future development, it is necessary to use examples of good practice and lifetime education in the technical implementation framework

The Law on State Survey and Cadastre adopted in 2009 provides the legal framework for the establishment of NSDI in Serbia, by transposing some provisions of the INSPIRE Directive. The Law defines NSDI through the following provisions: NSDI subjects (stakeholders), establishment, content, metadata, spatial datasets and services, The National Geoportal, constraints, NSDI bodies and competencies of the NSDI Council.

Full transposition will be achieved through the new Law on NSDI. The initial version of the Law on NSDI is drafted as well as discussed in several sessions with stakeholders.

The current national capacities for establishment of the NSDI within responsible public authorities are not sufficient. There is a particularly prominent need for provision of sufficient and competent human resources considering complexity of the INSPIRE implementation in the technical aspect.

Terms for data and service sharing are not fully set up according to the INSPIRE Implementing Rules.

The draft policy for the sharing and distribution of geodata within the NSDI framework was discussed on the NSDI Council and the working groups' sessions, as a starting point for determining the basic principles for cooperation.

The draft of document above gives an overview of contemporary trends at the global geoinformation market. There is an emphasis on the difference in practice regarding funding and data sharing between public authorities, with a focus on growing need for geodata accessibility and sharing under favourable conditions. It was noted that the balance should be established between the users' needs for favourable conditions for the access to geodata and data providers' needs to ensure adequate resources for financing the production and maintenance of data and services, in line with the INSPIRE Directive principles.

Development of a feasible business model for data provision and favourable terms for data sharing is a precondition for achieving sustainable environment for the INSPIRE Directive implementation. In line with the INSPIRE Directive principles, the key factor for the successful establishment of the NSDI are applicable terms for cooperation between NSDI stakeholders, with the focus on sustainable financing of the reference data provision, aiming to support the 'Open Data' initiative. In addition, close link to the e-government is the backbone to development of efficient e-government services.

Future development of the NSDI will be supprted by the World Bank under the proposed loan to the Government of Serbia for the Real Estate Management Project $(2015 \div 2020)$ - Among the other components, it proposes subcomponent B.2 Support to NSDI through the following activities:

- NSDI business model development (financing model, pricing policy, spatial data sharing and distribution among stakeholders, licensing, cost-benefit analysis, spatial data and services access for emergencies);

- Development of the NSDI technical framework by upgrading network services for discovery, view, transformation, download and linking spatial data services in line with the INSPIRE requirements;

- Data harmonization for themes under competence of the RGA. Analyses of the RGA's data sets current status regarding compliance with the INSPIRE data models, aiming to cover the existing gaps and plan for data harmonisation with the priorities defined.

\section{Conclusions}

After researching the level of NSDI technical implementation development achieved in Serbia, the conclusion may be drawn that the main components of the INSPIRE Directive are included in creation of data, metadata and network services. We may note that network services for spatial data sets and services with metadata produced in line with the INSPIRE Directive exist at the national level.

In the NSDI technical implementation process, some of the necessary preconditions have been provided: components operate on various platforms, system consists of various vendors' components, services are available over the Internet, existing services operate within the network services, and availability of the existing functionalities to the other applications is provided. Geoportals in practical use are providing for viewing and sharing distributed geospatial data and services.

It is necessary to note that there is a significant synergy of the GNSS technology and the NSDI concept influence on spatial data use and governance processes.

\section{Acknowledgements}

This paper was prepared as a part of the project "Serbian geodetic infrastructure advancement for the needs of a modern state survey" (TD 36020) financed by the Ministry of Education and Science of the Republic of Serbia within the framework of integrated and interdisciplinary research and technology development for the period $2011 \div 2015$ (Realization: University of Belgrade - Faculty of Civil Engineering of Belgrade and Technical University of Novi Sad - Faculty of Civil Engineering of Subotica).

\section{References}

[1] Aleksić, R. I. INSPIRATION-Spatial Data Infrastructure in the Western Balkans-Country Report SERBIA. The European Union's IPA Programme: Reference $N^{\circ}$ : 2011 /281-381, Project Identification No. EuropeAid /130907/ C/SER/ Multi. Publisher: GDi Gisdata, Zagreb, 2013.

[2] Aleksić, Lj. Students education of subjects in Bassic designing hauses on Civil Engineering Faculty Subotica. // Internattional scientific conference and XXIV meeting of Serbian surveyors "Profesional practice and education in geodesy and related fields", Kladovo, 2011, pp. 458-463. 
[3] Aleksić, Lj. Designing the Integral model of catalogue projecting. //International Conference "Architecture and Urbanism at The Turn of The III Millennium", Volume 2, Faculty of Architecture University of Belgrade, Belgrade, 1996, pp. 217-222.

[4] Bačić, Ž.; Aleksić, R. I.; Ključanin, S.; Lipej, B.; Poslončec P. V. Synergetic influence of INSPIRE and GNSS on spatial information providers and users in Adriatic region. // 8th INSPIRE Conference / Aalborg, Denmark, 2014. URL:https://bib.irb.hr/prikazi-rad?\&rad=701893 (2014.)

[5] Cetl, V.; Toth, K.; Abramić, A.; Smits, P. Report on the status of Inspire in the Balkan countries. Joint Research Center, Institute for Environment and Sustainability, Publications office of the European Union, EUR-Scientific and Technical Research series, Luxemburg, 2013.

[6] European Commission. Directive 2007/2/EC of the European parliament and of the council of March 14, 2007 instituting an Infrastructure for spatial information in the European community (INSPIRE), 2007.

[7] Konecny, G.; Hermsmeyer, D. Considerations for an NSDI Serbia. Republic Geodetic Authority, Belgrade, 2006.

[8] Kuburić, M.; Ćirović, G.; Kapović, Z. Estimation of Bridges through Implementation of Rough Sets Theory. // Tehnicki vjesnik-Technical Gazette. 19, 4(2012), pp. 781793.

[9] Poslončec, P. V. INSPIRATION-Spatial Data Infrastructure in the Western Balkans - Country Report CROATIA. The European Union's IPA Programme: Reference $N^{\circ}$ : 2011/281-381, Project Identification No. EuropeAid/130 907/C/SER/Multi. Publisher: GDi Gisdata, Zagreb, 2013.

[10] Rašković, M; Aleksić, R. I. Geo-sector Status Overview in the Republic of Serbia. // GEONAUKA - Serbian Union of Surveyors. 1, 2(2013), pp. 9-16.

\section{Authors' addresses}

Ivan R. Aleksić, Ph.D., full professor

University of Belgrade-Faculty of Civil Engineering Bulevar Kralja Aleksandra 73, 11000 Belgrade, Serbia aleksic@grf.bg.ac.rs

Miroslav Kuburic, Ph.D., assistant professor

Technical University of Novi Sad-Faculty of Civil Engineering Kozaračka 2a, 24000 Subotica, Serbia geodelta@geoput.com

Ljiljana Aleksić, Ph.D., assistant professor

Technical University of Novi Sad-Faculty of Civil Engineering Kozaračka 2a, 24000 Subotica, Serbia ljiljana.d.aleksic@gmail.com 